Medical Professionalism

in the New Information Age 



\section{Medical Professionalism in the New Information Age}

Edited by

David J. Rothman and David Blumenthal

Rutgers University Press

New Brunswick, New Jersey, and London 


\section{Library of Congress Cataloging-in-Publication Data}

Medical professionalism in the new information age / edited by David J. Rothman and David Blumenthal.

$$
\text { p. ; cm. - (Critical issues in health and medicine) }
$$

Includes bibliographical references and index.

ISBN 978-0-8135-4807-4 (hardcover : alk. paper) — ISBN 978-0-8135-4808-1 (pbk. : alk. paper)

1. Medical informatics. 2. Medical policy. 3. Medicine-Practice. I. Rothman, David J. II. Blumenthal, David, 1948- III. Series: Critical issues in health and medicine.

[DNLM: 1. Medical Informatics-trends-United States. 2. Professional Practicetrends-United States. W 26.5 M4899 2010]

R858.M46 2010

$610.285-\mathrm{dc} 22$

2009048327

A British Cataloging-in-Publication record for this book is available from the British Library.

This collection copyright @ 2010 by Rutgers, The State University

Individual chapters copyright ( $\odot 2010$ in the names of their authors

All rights reserved

No part of this book may be reproduced or utilized in any form or by any means, electronic or mechanical, or by any information storage and retrieval system, without written permission from the publisher. Please contact Rutgers University Press, 100 Joyce Kilmer Avenue, Piscataway, NJ 08854-8099. The only exception to this prohibition is "fair use" as defined by U.S. copyright law.

Visit our Web site: http://rutgerspress.rutgers.edu

Manufactured in the United States of America 